\title{
EUROPEAN UNION DO NOT WORRY, CROATIA IS BEHIND YOU: A COMMENTARY ON THE SEVENTH ACCESSION TREATY
}

\begin{abstract}
Adam Łazowski*
Summary: With the signature of the Accession Treaty, Croatia has entered the final stage of rapprochement. If everything goes according to plan, on 1 July 2013 Croatia will become the twenty-eighth Member State of the European Union. This article provides an analysis of the terms and conditions of membership. It looks at the institutional framework for accession as well as substantive rules, including transitional periods. It also takes on board a monitoring mechanism established to facilitate verification of Croatia's compliance with commitments undertaken during the accession negotiations and a set of safeguard clauses.
\end{abstract}

\section{Introduction}

On 9 December 2011 Croatia and twenty-seven Member States of the European Union signed the Accession Treaty. ${ }^{1}$ This has opened the last phase of Croatia's rapprochement, which is expected to lead to the accession on 1 July 2013. The timing could not be worse and perfect at the same time. On the one hand, the Seventh Accession Treaty was signed a few hours before one of many 'Euro-saving' meetings of the European Council was supposed to start. As well known, the latter ended with a strong disagreement between the United Kingdom and the other Member States as to the future so-called Fiscal Compact Treaty. ${ }^{2}$ This

\footnotetext{
Reader in Law, School of Law, University of Westminster, London. The author is grateful to Professor Tamara Ćapeta for her invaluable insights into Croatian law and Professor Christophe Hillion for interesting comments regarding the date of entry into force of the Accession Treaty.

1 Treaty between the Kingdom of Belgium, the Republic of Bulgaria, the Czech Republic, the Kingdom of Denmark, the Federal Republic of Germany, the Republic of Estonia, Ireland, the Hellenic Republic, the Kingdom of Spain, the French Republic, the Italian Republic, the Republic of Cyprus, the Republic of Latvia, the Republic of Lithuania, the Grand Duchy of Luxembourg, the Republic of Hungary, the Republic of Malta, the Kingdom of the Netherlands, the Republic of Austria, the Republic of Poland, the Portuguese Republic, Romania, the Republic of Slovenia, the Slovak Republic, the Republic of Finland, the Kingdom of Sweden, the United Kingdom of Great Britain and Northern Ireland (Member States of the European Union) and the Republic of Croatia concerning the accession of the Republic of Croatia to the European Union [2012] OJ L112/10.

2 Treaty on Stability, Coordination and Governance in the Economic and Monetary Union between the Kingdom of Belgium, the Republic of Bulgaria, the Kingdom of Denmark, the
} 
dispute forced the Member States to step outside the EU framework and conclude a classic international law treaty. The front pages of newspapers screamed about the crisis of the integration project and the inevitable demise of the common currency. In hindsight, we know that the latter survived (for the time being), yet at a high cost and against the economic reality and destructive approach of some of the Member States. On the other hand, there was Croatia with a firm belief that the integration project remains alive and consistently one of the priorities of its foreign policy. As if the Croatian authorities wanted to demonstrate that the closest neighbours still believed in the European Union, despite the malaise and wobbly politics in the eurozone. ${ }^{3}$ A referendum organised in Croatia soon after the signing of the Accession Treaty proved that this belief was not only shared by the political elite but also by Croatian society at large. ${ }^{4}$ As if the voters wanted to say: 'European Union do not worry, Croatia is behind you'. History will tell, possibly in years to come, whether the accession itself as well as its timing was right or wrong and whether the benefits outweighed the losses. It will also put to the test a rather bold and optimistic statement of the European Commission made in 2011 that

[t]he completion of accession negotiations with Croatia, opening the way to membership in mid-2013, vindicates the policy adopted in the aftermath of the devastating Balkan conflicts of the 1990s [...] it is [a] fresh evidence for the transformational power of the EU's enlargement policy [...]. ${ }^{5}$

Federal Republic of Germany, the Republic of Estonia, Ireland, the Hellenic Republic, the Kingdom of Spain, the French Republic, the Italian Republic, the Republic of Cyprus, the Republic of Latvia, the Republic of Lithuania, the Grand Duchy of Luxembourg, Hungary, Malta, the Kingdom of the Netherlands, the Republic of Austria, the Republic of Poland, the Portuguese Republic, Romania, the Republic of Slovenia, the Slovak Republic, the Republic of Finland and the Kingdom of Sweden, text available at <http://www.european-council. europa.eu/media/639235/st00tscg26_en 12.pdf> accessed 30 September 2012. For a commentary see, inter alia, P Craig, 'The Stability, Coordination and Governance Treaty: Principles, Politics and Pragmatism' (2012) 37 EL Rev 231,248.

3 The drive towards the European Union is not a Croatian spécialité de la maison. Other Western Balkan countries, as well as Turkey and Iceland, are also in the queue for membership. Iceland, Turkey, the Former Republic of Macedonia, Montenegro and Serbia have the status of candidate countries. Albania, Kosovo and Bosnia and Herzegovina are potential candidates, although Albania is seemingly on the path to candidate status. For recent developments and progress (or lack of it) towards accession, see Commission, 'Enlargement Strategy and Main Challenges 2012-2013' (Communication) COM (2012) 600 final.

4 In total, $66.27 \%$ of the votes were cast in favour and $33.13 \%$ of the votes were against membership in the European Union. See further, inter alia, A C ovic , 'Croatia's EU Accession Referendum 22 January 2012', Referendum Briefing No 18, Sussex European Institute <http:// www.sussex.ac.uk/sei/documents/epern-ref-no18.pdf> accessed 9 November 2012.

5 Commission, 'Enlargement Strategy and Main Challenges 2011-2012' (Communication) COM (2011) 666 final, 2 
In November 2012, when this article went to print, the ratification of the Accession Treaty was slowly moving forward and the accession still pencilled in for 1 July 2013. On 10 October 2012, the European Commission published, most likely, one of the last pre-accession reports on Croatia's progress towards the accession. ${ }^{6}$ Seemingly, the signals from Brussels were positive, although still quite a few crucial reforms were on the 'to-do list' drafted for Croatia. Furthermore, more reporting activity was scheduled for the remainder of the ratification period.

Bearing the above in mind, the timing seems perfect to take a closer look at the Seventh Accession Treaty and the terms of membership it provides for. The starting point is an overview of the structure, the rules on entry into force, the legal character of the Seventh Accession Treaty, as well as the accession of Croatia to the Founding Treaties forming the core of EU's primary law and some of their most recent modifications. ${ }^{7}$ That section is followed by analysis of the institutional provisions facilitating the phasing-in of the Croatian authorities into the EU decisionmaking machinery. It is important to take a look at both the institutional framework for the period between the signature of the Accession Treaty and following its entry into force. This will lead to an analysis of the immediate effect of EU law and the threats to the effective application of EU law after the accession. Adaptations to the existing EU acquis and transitional periods are analysed in turn. In the last part of the article, pre- and post-accession conditionality is elaborated, and the safeguard clauses laid down in the Accession Treaty are discussed in detail.

\section{Seventh Accession Treaty - the basics}

\subsection{Structure of the Seventh Accession Treaty}

The structure of the Seventh Accession Treaty is not original by any stretch of the imagination. To a large extent, it follows the model set up by the most recent Accession Treaties regulating membership of ten Central and Eastern European Countries, as well as Malta and Cyprus. ${ }^{8}$ The

6 Commission, 'Main Findings of the Comprehensive Monitoring Report on Croatia's state of preparedness for EU membership' (Communication) COM (2012) 601 final.

7 Consolidated versions of the Treaty on European Union and the Treaty on the Functioning of the European Union [2012] OJ C326/1 and Consolidated version of the Treaty establishing the European Atomic Energy Community [2012] OJ C327/1.

8 Treaty between the Kingdom of Belgium, the Kingdom of Denmark, the Federal Republic of Germany, the Hellenic Republic, the Kingdom of Spain, the French Republic, Ireland, the Italian Republic, the Grand Duchy of Luxembourg, the Kingdom of the Netherlands, the Republic of Austria, the Portuguese Republic, the Republic of Finland, the Kingdom of Sweden, the United Kingdom of Great Britain and Northern Ireland (Member States of the European Union) and the Czech Republic, the Republic of Estonia, the Republic of Cyprus, 
Seventh Accession Treaty is naturally a much shorter and compact affair as it determines the terms of accession of one state only. A short Accession Treaty sensu stricto is followed by a quite comprehensive Act on Conditions of Accession (the Act) providing for institutional and substantive terms of accession. Nine annexes regulate the nitty-gritty details of, inter alia, adaptations to the existing EU acquis, transitional periods, as well as specific commitments undertaken by Croatia. ${ }^{9}$ Furthermore, the parties agreed to a tailor-made protocol dealing with the implications stemming from accession to the regime laid down in the Kyoto Protocol to the United National Framework Convention on Climate Change. Both the Accession Treaty sensu stricto and the Act on Conditions of Accession with all the annexes and the Protocol constitute the Accession Treaty sensu largo. It is supplemented by the Final Act and non binding declarations. ${ }^{10}$

the Republic of Latvia, the Republic of Lithuania, the Republic of Hungary, the Republic of Malta, the Republic of Poland, the Republic of Slovenia, the Slovak Republic, concerning the accession of the Czech Republic, the Republic of Estonia, the Republic of Cyprus, the Republic of Latvia, the Republic of Lithuania, the Republic of Hungary, the Republic of Malta, the Republic of Poland, the Republic of Slovenia and the Slovak Republic to the European Union [2003] OJ L236/17. Treaty between the Kingdom of Belgium, the Czech Republic, the Kingdom of Denmark, the Federal Republic of Germany, the Republic of Estonia, the Hellenic Republic, the Kingdom of Spain, the French Republic, Ireland, the Italian Republic, the Republic of Cyprus, the Republic of Latvia, the Republic of Lithuania, the Grand Duchy of Luxembourg, the Republic of Hungary, the Republic of Malta, the Kingdom of the Netherlands, the Republic of Austria, the Republic of Poland, the Portuguese Republic, the Republic of Slovenia, the Slovak Republic, the Republic of Finland, the Kingdom of Sweden, the United Kingdom of Great Britain and Northern Ireland (Member States of the European Union) and the Republic of Bulgaria and Romania, concerning the accession of the Republic of Bulgaria and Romania to the European Union [2005] OJ L157/11. For a legal appraisal see, inter alia, K Inglis, The Union's Fifth Accession Treaty: New Means to Make Enlargement Possible' (2004) 41 CML Rev 937; Ch Hillion, 'The European Union is Dead. Long Live the European Union: A Commentary on the Treaty of Accession 2003' (2004) 29 EL Rev 583, 612; A Łazowski, 'And Then They Were Twenty-Seven: A Legal Appraisal of the Sixth Accession Treaty' (2007) 44 CML Rev 401.

9 Annex I contains a list of conventions and protocols to which Croatia has the obligation to accede upon accession; Annex II contains a list of provisions of the Schengen acquis, which will apply to Croatia as of the date of accession; Annex III deals with the adaptations to EU secondary legislation; Annex IV with permanent modifications to the existing EU acquis; Annex V regulates the transitional periods; Annex VI provides for a temporary regime for additional rural development measures for Croatia; Annexes VII-IX provide for specific commitments undertaken by Croatia during the accession negotiations (in the JHA and state aid areas).

10 Joint Declaration by the Member States on the full application of the Schengen acquis; Joint Declaration by Germany and Austria on free movement of workers and Joint Declaration of the Member States and Croatia on the European Development Fund. 


\subsection{Entry into force of the Seventh Accession Treaty}

The next issue that should be addressed is the date of entry into force of the Seventh Accession Treaty. ${ }^{11}$ It is notable that the accession has been pencilled in for 1 July 2013, providing all ratification documents are deposited with the Italian Government by 30 June 2013. ${ }^{12}$ As a matter of exception, article 36 of the Act, which lays down a framework for a pre-accession monitoring mechanism, has become applicable as of the date of signature of the Seventh Accession Treaty. ${ }^{13}$ Analysis of these provisions, particularly article 3(3) of the Accession Treaty, leaves one somewhat perplexed. It is notable that no modus operandi is provided that would apply if one or more of the twenty-seven Member States failed to ratify it within the envisaged time framework. To put it differently, there is no plan B. ${ }^{14}$ On the one hand, one could simply conclude nihil novi: this is a traditional approach, known from the previous Accession Treaties. A calendar date should keep the current Member States alert to the necessity of timely ratification and, at least in theory, guard the contracting parties from unnecessary procedural procrastination. On the other hand, it does not take into account any potential ratification problems. As well known, Croatia's rapprochement has not been a bed of roses all the way along and has encountered a variety of problems in several Member States of the European Union. Relations with Slovenia have been undermined by the border dispute and other thorny issues related to the painful Yugoslavian legacy. ${ }^{15}$ Furthermore, several Member States questioned Croatia's compliance with the entry conditions and decided to wait with ratification of the Seventh Accession Treaty. ${ }^{16}$ When this article went to print (November 2012) only half of the existing Member States had ratified the Treaty in question. One should emphasise that a delay in ratification of the Accession Treaty would have not only politi-

\footnotetext{
11 It should be emphasised that with the entry into force of the Accession Treaty the life of the Stabilisation and Association Agreement between the European Union and Croatia will come to an end.

12 Art. 3(1) of the Accession Treaty.

13 See further section 7.2 of this article.

14 A comparison with the revision treaties, for instance the Treaty of Lisbon, reveals an interesting phenomenon. The latter set calendar dates, too, although they also contain alternative options applicable should delays in ratification occur.

15 Furthermore, ratification of the Seventh Accession Treaty has encountered political problems in the Polish Parliament, where the right wing opposition party PiS led by Jarosław Kaczyniski decided to open the next phase of its Eurosceptic bonanza. As is often the case, it turned into a classic storm in a tea cup and the Parliament eventually authorised the Polish President to ratify the Treaty.

16 See, inter alia, EurActiv Network, 'German Skepticism on EU Enlargement Hits at Croatia' (15 October 2012) <http://www.euractiv.com/enlargement/german-enlargementskepticism-hi-news-515410> accessed 10 November 2012.
} 
cal consequences but would also trigger several legal questions (for instance, concerning the status of calendar deadlines laid down in Annex $\mathrm{V}$ dealing with transitional periods?).

Notwithstanding the idiosyncrasies of Croatian accession, one should emphasise that doubts and reservations as to the credentials of the newcomers have become a permanent feature of the enlargement debate during the last ten years. The accession of Bulgaria and Romania proved to be very problematic to the extent that the Accession Treaty 2005 contained an unprecedented procedure allowing the European Union to delay membership by one year. ${ }^{17}$ It is interesting to note that no comparable modus operandi is available in the Seventh Accession Treaty, giving a somehow misleading impression that ratification is a fait accompli. Since this may not be the case, it would be interesting to engage in a bit of academic speculation and consider the available options. These may be sought in EU law as well as in public international law.

To start with, one could imagine the entry into force of the Accession Treaty on the day the last country deposits the ratification documents with the Italian Government. Alternatively, one may also consider a revision of the Seventh Accession Treaty. To this end, article 7 of the Act provides that amendments may be adopted in accordance with procedures laid down in article $48 \mathrm{TEU}$. Literal interpretation of article 7 may lead to a conclusion that it applies exclusively to the Act on Conditions of Accession. However, it is reasonable to argue that it might be an option to apply the same provision mutatis mutandis to the Accession Treaty sensu largo. Still, if this path is followed, such a revision of the Accession Treaty will require ratification by Croatia as well as all by Member States of the European Union. This would be as controversial as it would be time consuming. With limited options available in EU law, one could venture into public international law in search of solutions. Arguably, the law of the treaties, particularly customary international law, might offer some solutions to this conundrum.

\subsection{Legal character of the Seventh Accession Treaty}

It should be noted that the Seventh Accession Treaty, just like its predecessors, was concluded between the existing Member States of the European Union and a candidate country (in this case Croatia). Contrary to the common perception, the European Union is not a party to accession treaties. Having said that, it is interesting to delve into the legal character of this legal act and the implications it may have for both the European Union and Croatian legal orders. When it comes to the

$\overline{17}$ See further, inter alia, Łazowski (n 8) 415, 416. 
hierarchy of sources of EU law, the Seventh Accession Treaty forms part of primary law. Just like the previous Accession Treaties, it regulates not only the terms of accession but it also amends the Founding Treaties of the European Union with a view to accommodating the new entrant. Being part of EU primary law, the Seventh Accession Treaty escapes the legality review as per article 263 TFEU. This, however, does not mean that judicial or constitutional review cannot be requested at the domestic level. ${ }^{18}$ Furthermore, the Court of Justice has the jurisdiction to deal with references for a preliminary ruling on interpretation of the Accession Treaty (article 267 TFEU).

At the same time, any direct or indirect challenges to the legality of the secondary legislation adopted on the basis of the Seventh Accession Treaty, without a shadow of doubt, fall under the EU judicial review modus operandi. ${ }^{19}$ There are a number of potential legal bases for such legislation, with article 51 of the Act being the prime example. It gives general competence to the Council of the European Union to adopt measures necessary for implementation of the Act. The Council does so on the initiative of the European Commission, acting by qualified majority. Interestingly enough, the European Parliament plays no role whatsoever. Further specific legal bases are scattered throughout the Act. ${ }^{20}$ As the previous accession rounds have proven, the adoption of secondary legislation containing amendments to the Accession Treaties, particularly when it has financial implications, is frequently controversial and the legality of such acts is sometimes challenged by the new Member States. Some of the recent judgments have raised the very contentious issue of the application of locus standi rules laid down in article 263 TFEU to the acceding countries. According to this line of case law, the two months' deadline for the submission of actions for annulment runs for the acceding countries from the date of accession, not from the date of publication of a legal act or its notification. This was implicitly acknowledged by the Grand Chamber in case C-273/04 Poland $v$ Council ${ }^{21}$ and was properly

\footnotetext{
18 This happened, for instance, in Poland when a group of members of the Polish Parliament challenged the compliance of the Accession Treaty 2003 with the Polish Constitution. See further, inter alia, A Łazowski, 'Poland. Constitutional Tribunal on Conformity of the Accession Treaty with the Polish Constitution. Decision of 11 May 2005' (2007) 3 European Constitutional Law Review 148.

19 This includes direct actions for annulment submitted in accordance with art 263 TFEU and preliminary ruling references (art $267 \mathrm{TFEU}$ ) questioning the validity of such legislation. See further on the previous practice, inter alia, S Kaleda, 'Intertemporal Legal Issues in the European Union Case Law Relating to the 2004 and 2007 Accessions' in A Łazowski (ed), The Application of EU Law in the New Member States (TMC Asser Press 2010).

20 See for instance art 35(3) giving the power to the European Commission to adopt implementing acts on rural development measures.

${ }^{21}$ Case C-273/04 Republic of Poland $v$ Council of the European Union [2007] ECR I-8925.
} 
explained and developed in recent Grand Chamber case C-336/09P Poland $v$ Commission. ${ }^{22}$ The rules established by the Court of Justice will now apply mutatis mutandis to Croatia, if it wishes to request judicial review of legal acts based on the Act.

\subsection{Accession to the Founding Treaties and the status of treaty revisions}

The entry into force of the Seventh Accession Treaty will have implications on the other legal acts comprising the EU primary legislation. First and foremost, the Seventh Accession Treaty contains a number of provisions amending the Founding Treaties of the European Union with the view to accommodating Croatia as a new Member State. It is notable that by becoming a party to the Seventh Accession Treaty Croatia also becomes a party to all three founding treaties - the Treaty on European Union, the Treaty on the Functioning of the European Union and the Treaty establishing the European Atomic Energy Community (all three as amended and supplemented). ${ }^{23}$ Although the Accession Treaty does not mention this expressis verbis, Croatia, by means of article 6 TEU, becomes also bound by the Charter of Fundamental Rights of the European Union. ${ }^{24}$

An interesting regulation which appears in the Seventh Accession Treaty is the explicit regulation of the status of the amending treaties, which were not in force or were not even negotiated before the date of signature of the Accession Treaty. Arguably, it was necessary to regulate these issues due to the number of pending and potential future treaty revisions. Interestingly enough, we find two provisions dealing with such revision treaties - article 3(2) of the Accession Treaty and article 2 of the Act. It is not clear why these two norms were given home by the law drafters in two different parts of the Treaty, and this is likely to remain their sweet secret. The first of these provisions determines the status of revisions of the Founding Treaties which were the subject of ratification procedures or approvals as per domestic constitutional requirements at the time of ratification of the Accession Treaty by Croatia. ${ }^{25}$ Article 3(2) of

22 Case C-336/09P Republic of Poland $v$ European Commission (ECR, 26 June 2012).

${ }_{23}$ See art 1(2) of the Accession Treaty. It is a different formula from the one used in the two previous accession rounds. For instance art 1(1) of the Accession Treaty 2003 provided for the automatic accession of the new Member States to "the Treaties on which the Union is founded as amended or supplemented'. A similar formula was used in the Accession Treaty 2005.

24 Subject to the caveat of art 51(1) of the Charter ('the provisions of this Charter are addressed [...] to the Member States only when they are implementing Union law').

25 In the case of decisions of the European Council adopted in accordance with one of the simplified revision procedures as per art 48(6-7) TEU. See further on the post-Lisbon treaty 
the Accession Treaty provides that Croatia is deemed to have ratified or approved those treaty revisions by means of ratification of the Seventh Accession Treaty. At the time of the drafting of the Treaty, there were two such revisions in the pipeline - the Protocol on the increase of the number of the members of the European Parliament ${ }^{26}$ and the Decision of the European Council 2011/199/EU amending article 136 TFEU. ${ }^{27}$ The first amendment, however, entered into force on 1 December 2011, that is eight days before the signature of the Seventh Accession Treaty. Consequentially, Croatia has become party to it by means of article 1 (2) of the Accession Treaty. Decision of the European Council 2011/199/EU has not yet entered into force, so article 3 (2) of the Accession Treaty applies. The next issue which merits attention is the status of the revisions of the Founding Treaties drafted after the signature of the Seventh Accession Treaty and which enter into force either before or after the accession of Croatia to the European Union. To some extent this issue is addressed in the already mentioned article 2 of the Act. In the case of amendments to the Founding Treaties, which were approved by the Member States after the ratification of the Accession Treaty by Croatia but which do not enter into force before the accession, Croatia has the obligation to ratify these amendments in accordance with the domestic constitutional requirements. Undoubtedly, this provision is an important clarification, yet it is not a very comprehensive one. There are two things it fails to deal with. First, revisions which, for the time being, hypothetically, can be negotiated, approved and which enter into force before 1 July 2013 (or, if applicable, before a later date of accession) are not covered. It is reasonable to assume that Croatia would be involved in such negotiations as an acceding country in the capacity of an observer. ${ }^{28}$ With the absence of relevant provisions in the Seventh Accession Treaty, one would expect to have this particular issue addressed in a revision treaty itself. For the time being this is merely an academic issue as no such amendments to the Founding Treaties were pending when this article went to print. However, a slightly different but related legal issue emerged in practice, mainly the status of two treaties dealing with the eurozone crisis which were concluded between some of the Member States outside the scope of EU law. This is the case with the Treaty establishing the European Sta-

revision modi operandi B de Witte, 'Treaty Revision Procedures after Lisbon' in A Biondi, $\mathrm{P}$ Eeckhout and S Ripley (eds), EU Law After Lisbon (OUP 2012) 107.

26 Protocol amending the Protocol on Transitional Provisions annexed to the Treaty on European Union, to the Treaty on the Functioning of the European Union and to the Treaty establishing the European Atomic Energy Community [2010], OJ C263/1.

27 Council Decision 2011/199/EU 25 March 2011 amending article 136 TFEU with regard to a stability mechanism for Member States whose currency is the euro [2011] OJ L91/1.

28 See further section 3 of this article. 
bility Mechanism (hereinafter ESM Treaty) ${ }^{29}$ and the already mentioned Treaty on Stability, Coordination and Governance. The status of Croatia vis-à-vis both treaties is regulated neither in the Accession Treaty nor in the Act. This, however, does not mean that we are operating in a complete legal vacuum as one may deduce a bit of clarification from both the ESM and the Fiscal Compact Treaties. To start with, the ESM Treaty applies only to the Member States of the European Union whose currency is the Euro. This, for the time being, will exclude Croatia from the list of contracting parties. However, it may be extended to other EU countries, including the newcomers, when they become part of the eurozone. ${ }^{30}$ This possibility will be available to Croatia when and if it decides to adopt the common currency and a request to this end is approved by the Council of the European Union. The Fiscal Compact Treaty is a slightly different kettle of fish. Twenty-five Member States are the contracting parties ${ }^{31}$ but it is open to other Member States (which, one may assume, applies also to the new Member States) when they express a desire to accede and to comply with the ratification requirements laid down in article 15 of that Treaty.

\subsection{Participation in the Economic and Monetary Union}

Traditionally, the new Member States have an obligation to accept participation in the Economic and Monetary Union. A contrario, no permanent opt-outs comparable to the one available to the United Kingdom or Denmark are available. At the same time, the new Member States do not introduce the Euro as their currency as of the date of accession. In this respect, the Seventh Accession Treaty is based on the model developed during the previous accession rounds. In accordance with article 5 of the Act, Croatia will participate in the Economic and Monetary Union as of the date of accession, however subject to the derogation stemming from article 139 TFEU. To that end, Croatia will have the status of 'a Member State with a derogation' and in order to introduce the Euro as its currency the standard procedure laid down in article 140 TFEU will apply.

\footnotetext{
29 Treaty establishing the European Stability Mechanism between the Kingdom of Belgium, the Federal Republic of Germany, the Republic of Estonia, Ireland, the Hellenic Republic, the Kingdom of Spain, the French Republic, the Italian Republic, the Republic of Cyprus, the Grand Duchy of Luxembourg, Malta, the Kingdom of the Netherlands, the Republic of Austria, the Portuguese Republic, the Republic of Slovenia, the Slovak Republic, the Republic of Finland, text available at <http://www.european-council.europa.eu/media/582311/05tesm2.en12.pdf> accessed 30 September 2012. For a commentary see, inter alia, M Ruffert, 'The European Debt Crisis and European Union Law' (2011) 48 CML Rev 1777.

30 See art 2 of the ESM Treaty.

31 The United Kingdom and the Czech Republic decided not to participate in this new endeavour.
} 


\subsection{Participation in the Schengen acquis}

The Seventh Accession Treaty also addresses the application of the Schengen acquis to Croatia. Again, the model developed in the previous accession rounds has been followed. As per article 4(1) of the Act, the provisions of the Schengen acquis are binding on Croatia as of the date of accession. ${ }^{32}$ However, some of them will apply in relation to it at a later date when the Council of the European Union takes a decision in this respect. This, as proven by the case of Bulgaria and Romania, is not a mere formality. It should be noted that article 4 of the Act provides a modus operandi that will apply. To start with, the Council will take a decision, only after verification in accordance with the Schengen evaluation procedures, on whether the necessary conditions for the application of the Schengen acquis are met. It is notable that the decision requires unanimity in the Council of the European Union and an opinion of the European Parliament. As explained in the Declaration of the Member States annexed to the Seventh Accession Treaty, this decision will be taken without prejudice to the rather contentious decisions on the full participation of Bulgaria and Romania in the Schengen acquis. For the latter, the relevant provisions of the Accession Treaty 2005 will apply.

\section{Institutional provisions - from observers to fully fledged members}

\subsection{Phasing in into the EU decision making machinery}

As with previous enlargements, phasing into the EU decision-making machinery is gradual and starts before accession to the European Union. There are two stages of this process which may be distinguished. For Croatia, the first stage started shortly after the signature of the Seventh Accession Treaty and will last until the date of accession. It comes from this that the second stage will commence with the entry into force of the Seventh Accession Treaty, when Croatian officials will formally join all institutions and organs constituting the European Union's institutional framework. The idiosyncrasies of both stages are broadly discussed below. This will lead readers to a detailed discussion of phasing into the key EU decision-making authorities as well as the Court of Justice of the European Union.

During the first stage, Croatian authorities are allowed to participate in the work of several EU institutions, although this is short of having full membership rights in any of them. When it comes to the European Council and the Council of the European Union, Croatian officials have the status of observers and Croatia benefits from the Information and Consultation Procedure. Details of the latter are outlined in a tailor-made agree-

32 For a list, see Annex II to the Seventh Accession Treaty. 
ment between the European Union and Croatia, which is annexed to the Seventh Accession Treaty. The benefits of this procedure are twofold. First, it allows, at least in theory, the Croatian government to shape pending proposals of EU legislation, which are adopted after the cut-off date of the accession negotiations but before accession to the European Union. This interim arrangement thus tackles 'grey zone' legal acts that Croatia will be bound by as of the date of accession, for which it did not have the opportunity to negotiate transitional periods during the accession negotiations and where it could not benefit from the prerogatives of a Member State. It is notable that the cut-off date for accession negotiations was 1 July 2011, so any legal act adopted after that date may be the subject of a special request made as per article 49 of the Act. ${ }^{33}$ Second, this interim phase between the signature of the Accession Treaty and its entry into force gives Croatia an opportunity to design the domestic EU policy co-ordination machinery and have a dry run to test its feasibility and functionality. As part of the Information and Consultation Procedure, Croatian authorities are fed on a daily basis with all new proposals for legal acts tabled by the European Commission and, whenever this is possible under the Founding Treaties, by other EU institutions or the Member States. ${ }^{34}$

It should be noted that Croatian representatives are not only involved in the work of the European Council and the Council of the European Union, but also the European Parliament. Despite a lack of legal basis in the accession treaties, parliaments of the acceding countries are traditionally invited to send observers to the Assembly.

\subsection{European Council and Council of the European Union}

Following the interim phase discussed in the previous sub-paragraph, Croatian nationals will start to participate, as fully fledged members, in the work of the European Council and the Council of the European Union as of the date of accession to the European Union. This, on the one hand, should not cause any major challenges to the work of both institutions and, on the other, should quickly become a routine for the Croatian delegates. What merits attention is the impact of the seventh enlargement on the voting rules in these institutions. As a matter

33 See further sub-section 5.3 of this article.

34 Any proposal, communication, recommendation or initiative which is intended to lead to the adoption of a legal act of the European Parliament and Council, the Council, or the European Council is brought to the attention of Croatian authorities. As a matter of principle, administrative decisions fall outside the scope of this procedure. Consultations are organised when requested by Croatia, which has the obligation to set out expressly its interests and observations. Should a request be submitted, the consultations take place within an Interim Committee composed of representatives of the EU and of Croatia. Consultations take place as soon as the preparatory work carried out at the EU level with a view to the adoption of the acts has produced common guidelines enabling such consultations to be usefully arranged. 
of fact, the accession of Croatia almost coincides with the implementation of the major reform introduced by the Treaty of Lisbon. Indeed, as of 1 November 2014, the new system will become operational, yet subject to some transitional rules allowing for the application of the old regime until 2017. Bearing this in mind, the accession of Croatia required revision of Protocol No 36 to the Founding Treaties which regulates currently applicable voting rules in the Council of European Union (which apply mutatis mutandis to the European Council) and the phasing in of the new modus operandi. Detailed rules amending this Protocol are provided in article 20 of the Act. First of all, in the period between accession and 1 November 2014 the following allocation of votes in the Council of the European Union and the European Council will apply.

\begin{tabular}{|l|r|}
\hline \multicolumn{1}{|c|}{ Member State } & Number of votes \\
\hline Belgium & 12 \\
\hline Bulgaria & 10 \\
\hline Czech Republic & 12 \\
\hline Denmark & 7 \\
\hline Germany & 29 \\
\hline Estonia & 4 \\
\hline Ireland & 7 \\
\hline Greece & 12 \\
\hline Spain & 27 \\
\hline France & 29 \\
\hline Croatia & 7 \\
\hline Italy & 29 \\
\hline Cyprus & 4 \\
\hline Latvia & 4 \\
\hline Lithuania & 7 \\
\hline Luxembourg & 4 \\
\hline Hungary & 12 \\
\hline Malta & 3 \\
\hline Netherlands & 13 \\
\hline Austria & 10 \\
\hline Poland & 27 \\
\hline Portugal & 12 \\
\hline Romania & 14 \\
\hline Slovenia & 4 \\
\hline Slovakia & 7 \\
\hline Finland & 7 \\
\hline Sweden & 10 \\
\hline United Kingdom & 29 \\
\hline
\end{tabular}


article 20 of the Act increases the limit for the adoption of legal acts to 260 votes in favour, representing a majority of the members ${ }^{35}$ when a proposal is tabled by the European Commission. In all other cases, the requirement is also 260 votes in favour, ${ }^{36}$ however subject to the caveat that they represent at least 2/3 of the members. As per article 3(3) of Protocol No 36, a member of the European Council or the Council of the European Union may request verification if the Member States, which comprise the majority, actually represent at least $62 \%$ of the overall population of the European Union. If that is not the case, a decision is not taken. It should be noted that as per this Protocol, between 1 November 2014 and 31 March 2017 the new decision making modus operandi laid down in article 16(4) TEU will not apply if a Member State (or a group of Member States) requests the application of the old system. Hence, the transitional rules, as amended by article 20 of the Act, may in fact apply until the end of March 2017.

\subsection{European Parliament}

As explained above, Croatia became partly involved in the work of the European Parliament shortly after the signature of the Accession Treaty. The mandate of twelve observers nominated by the Croatian Parliament will end with the accession to the European Union. From that moment on, Croatia will have the right to have twelve fully fledged members of the Assembly. This will bring the total number of MEPs to 766 and will have to be reduced with the next term of the European Parliament (2014-2019) to align it with the limit laid down in article 14(2) TEU. ${ }^{37}$ The rules for the appointment of MEPs in Croatia, laid down in article 19 of the Act, merit attention for two reasons. Firstly, these are different to the modi operandi employed in the previous enlargement rounds. Secondly, their interpretation raises a number of interesting questions that are dealt with in the next paragraph.

In the case of the past five enlargement rounds, ${ }^{38}$ the new Member States were given the right to nominate representatives to the Assembly from among the domestic parliamentarians. At the same time, the Accession Treaties provided deadlines for general elections to the European

\footnotetext{
35 Currently 255 votes.

36 Currently 255 votes.

37750 Members plus the President of the European Parliament.

38 The situation was different with the first enlargement, as at that time the Act on Direct Elections had not been adopted yet and members of the European Parliament were nominated by the national legislatures.
} 
Parliament in the new Member States. ${ }^{39}$ These rules have been modified in the Seventh Accession Treaty. To start with, article 19 (2) of the Act imposes an obligation for Croatia to organise elections to the European Parliament before the date of accession to the European Union. Furthermore, elections will have to be conducted in accordance with the European Union acquis. In order to address this obligation the Croatian Parliament already in 2010 (that is, well before the completion of the accession negotiations) adopted an Act on the Elections to the European Parliament. ${ }^{40}$ Although this arrangement seems reasonable it raises some doubts, to say the least. The first question is when exactly Croatia should ask the voters to go to the polls. It would be reasonable to do so close to the scheduled date of accession when it is certain that all twenty-seven Member States will ratify the Seventh Accession Treaty. What if the elections take place and a delay in the accession process occurs? What will be the status of such elected MEPs in the transitional period? Will they take over the tasks from Croatian observers and maintain such status until the date of accession? Although such questions were hypothetical at the time of writing of this article, they should nevertheless be taken account as the final stages of rapprochement may not be fait accompli. The requirement to conduct elections in accordance with the EU acquis also merits comment. The wording of article 19 (2) of the Act is quite vague and open to various interpretations. No doubt, the umbrella terms employed there refer to Decision 76/787/ECSC, EEC, Euratom on elections to the European Parliament. ${ }^{41}$ The question is if it also covers Directive 93/109/EC on the rights of EU citizens to vote and stand in elections to the European Parliament in the country of residence, which is not the country of nationality. ${ }^{42}$ If this is the case, it would amount to the pre-accession application of EU law and would give voting rights to EU citizens already residing in Croatia. Such interpretation is not an act of heresy, yet if it is correct it raises further questions. Would such voters, in the case of post-electoral disputes, have the right to challenge the decisions of the electoral commissions (for instance, registering candidates) and then, in the case of non-compliance of Croatian voting

39 According to art 24(2) of the Act on Conditions of Accession of Bulgaria and Romania, both countries had the obligation to hold elections to the European Parliament during the first year of membership in the European Union.

40 Zakon o izborima zastupnika iz Republike Hrvatske u Europski parlament (Narodne novine, br 92/10).

41 Council Decision 76/787/ECSC, EEC, Euratom of 26 September 1976 of the representatives of the Member States meeting in the council relating to the Act concerning the election of the representatives of the Assembly by direct universal suffrage [1976] OJ L278/1.

42 Council Directive 93/109/EC of 6 December 1993 laying down detailed arrangements for the exercise of the right to vote and stand as a candidate in elections to the European Parliament for citizens of the Union residing in a Member State of which they are not nationals [1993] OJ L329/34. 
rules with the Directive, rely on the direct effect of the latter? What if this Directive is not yet available in Croatian in the Special Edition of the Official Journal of the European Union by then? Will the principles laid down in case C-161/06 Skoma-Lux case ${ }^{43}$ apply in cases submitted by individuals against state authorities? One can only speculate on how these questions should be answered. Another interesting point is the modus operandi provided in article 19 paragraph 2 of the Act which will apply if there is a delay in the accession process. It is surprising to see a plan B for elections to the European Parliament, but not for accession as such. As discussed above, the Accession Treaty provides a calendar date for accession and no alternative. In the discussed provision, however, the possibility of a delay is explicitly mentioned but only in a particular context. If the elections in Croatia were to take place in the last six months before the scheduled elections to the European Parliament, then the Croatian Parliament will have the competence to nominate twelve MEPs for that interim period, providing they have been elected by direct universal suffrage.

Practice will prove whether the doubts raised above will materialise or will remain a purely academic conundrum. Either way, it is fairly clear that article 19 of the Act would benefit from much better drafting. If any problems arise, this will be a bonanza for lawyers, yet a rather short one as all issues discussed above are of an intertemporal character.

\subsection{European Commission}

Croatia, just like all other Member States of the European Union, will benefit from the one-Commissioner-per-state rule. In accordance with article 21 of the Act, a Croatian national will be appointed as a member of the College as of the date of accession. The term of the Croatian commissioner will end together with the five-year term of the Barosso II Commission (31 October 2014 or any later date should the term be extended). The procedure for the appointment of the Croatian commissioner envisaged by article 21 (1) of the Act is similar to the modus operandi laid down in article $246 \mathrm{TFEU}$ applicable to the filling of vacancies during the term of the College. The appointment will be made by the Council of the European Union in common accord with the President of the European Commission and after consultations with the European Parliament. The criteria for appointment will be just the same as in the case of other members of the European Commission. ${ }^{44}$ It should be added that before the appointment of the European Commission for the term 2014-2019,

43 Case C-161/06 Skoma-Lux sro v Celní editelství Olomouc [2007] ECR I-10841.

44 As per art 17(3) TEU, candidates shall be chosen on the ground of their general competence and European commitment from persons whose independence is beyond doubt. 
a decision should be made as to the number of members of the College. In accordance with the regime laid down in article 17(5) TEU, as from 1 November 2014 the Commission shall consist of a number of members corresponding to 2/3 of the number of the Member States (unless the European Council decides to alter this number). However, the question remains if there will be enough political will among the Member States to come to an agreeable solution and to reduce the number of commissioners. It may well be that the one-Commissioner-per-state rule will apply beyond 2014. However, if the reduction of the size of the college of commissioners becomes a reality, the question emerges if a Croatian national will be eligible for appointment. The Seventh Accession Treaty is silent on this point, yet, by being a Member State, Croatia will participate in the negotiations from the very start (providing they commence after the seventh enlargement).

\subsection{Court of Justice of the European Union}

As of the date of accession to the European Union, Croatia will have the right to have one judge at the Court of Justice and one at the General Court. By this token, the composition of both EU courts will be twentyeight judges each. ${ }^{45}$ As per article 22 of the Act, the term of the Croatian judge at the Court of Justice will expire on 6 October 2015 and the term of the judge at the General Court on 31 August 2013. The latter is quite puzzling and, should accession be delayed beyond 1 July 2013, a revision of this provision will be necessary. ${ }^{46}$ For the appointment of both judges, the standard set of rules laid down in article 19 (2) TEU will apply. Candidates proposed by the Croatian authorities will be evaluated by the Special Committee established as per article 255 TFEU. If they pass that hurdle, the appointments will be made by a unanimous decision of the Member States.

Croatia, just like the majority of other Member States, will not have a permanent right to have an advocate general at the Court of Justice. To put it differently, it will be subject to the well-established rotation system based on alphabetical order. The same will apply for the appointment of judges to the Civil Service Tribunal. In both cases, the standard modi operandi for appointment will apply.

\footnotetext{
45 Unless the pending proposal to increase the number of judges at the General Court becomes a law beforehand.

46 See section 2.2 above.
} 


\subsection{Advisory bodies, agencies and organs of the European Union}

Being a fully fledged Member State of the European Union, Croatia will have the right to nominate its representatives to advisory bodies, agencies and other organs of the European Union. The participation of Croatian representatives in the Economic and Social Committee, as well as the Committee of the Regions, is explicitly regulated in the Act. ${ }^{47}$ In both advisory bodies, Croatia will have nine representatives, which will temporarily increase the total number of members to 353. Since it is above the threshold of 350 members laid down in articles 301 and 305 TFEU (respectively), it is likely to be addressed in decisions of the Council of the European Union determining the composition of both advisory bodies. In relation to the European Investment Bank, article 25 of the Act specifies that the term of office of the Croatian director of the Board of Directors of EIB will expire during the annual meeting of the Board when it examines a report for 2017. Article 10 of the Act also provides for further structural changes to the composition of the Board of Directors of the EIB and, to this end, amends the Protocol on the Statute of the European Investment Bank annexed to the Founding Treaties. Furthermore, membership in the Euratom Scientific and Technical Committee is increased from 41 to 42 by means of article 11 of the Act. ${ }^{48}$ When it comes to other organisational units falling under the EU institutional umbrella, the appointment of Croatian representatives will be conducted in accordance with the general rules governing the functioning of those committees, groups, agencies and other bodies. ${ }^{49}$

\section{Immediate effect of EU Law}

\subsection{The principle of immediate effect of EU law}

Traditionally new Member States become a part of the legal order of the European Union as of the date of accession. ${ }^{50}$ This is in accordance with the principle of immediate effect of EU law, which, in the case of Croatia, is laid down in articles 2 and 46 of the Act. The first provision provides that from the date of accession the Founding Treaties as well as the acts adopted by the EU institutions are binding on Croatia. In accordance with the latter provision, Croatia is an addressee of directives and decisions as per article 288 TFEU. Similarly to the previous Accession Treaties, the drafters seemingly forgot to add framework decisions to the

\footnotetext{
47 Arts 23 and 24 of the Act (respectively).

48 Art 11 of the Act amends art 134(2) of the EAEC Treaty.

49 See art 26 of the Act.

50 See further, inter alia, S Kalèda, 'Immediate Effect of Community Law in the New Member States' (2004) 10 European Law Journal 102.
} 
list. ${ }^{51}$ As per article 47 (1) of the Act, Croatia has the obligation to put into effect domestic measures to give effect to directives and decisions. This is combined with the standard obligation to notify those measures to the European Commission by the date of accession (unless transitional periods apply to Croatia). Again, framework decisions are not listed, nor are EU regulations, which may sometimes require implementation at the domestic level (despite being directly applicable). Although not regulated explicitly in the Seventh Accession Treaty, Croatia also has the obligation to repeal provisions of domestic law which copy self-executing provisions of EU legislative, implementing and delegated regulations. article 47 (2) of the Act also imposes an obligation on the existing Member States to put into effect national measures necessary to comply with the directives amended as a result of the accession of Croatia to the European Union.

\subsection{Obstacles and threats to the effective application of EU law}

Although the Seventh Accession Treaty provides for the immediate effect of EU law, this does not translate into the unproblematic application of EU law as of the date of accession. As previous accession rounds prove, there are a number of fundamental obstacles and threats that EU law faces in the new Member States. The first major problem is the timely publication of the Official Journal of the European Union in the languages of the newcomers. ${ }^{52}$ Although it is almost certain that daily issues of the Official Journal will be published in Croatian as of the date of accession, they will only contain the post-accession EU acquis. ${ }^{53}$ It is the publication of the pre-accession acquis in the Special Edition of the Official Journal that traditionally remains a major challenge, not to mention an exorbitant expense for the newcomers and the European Union alike.

\footnotetext{
51 In the period between the Treaties of Amsterdam and the Treaty of Lisbon, framework decisions remained the key legal instrument adopted in the former Third Pillar of the European Union. They were addressed to the Member States and always required transposition to national law. The definition of framework decisions laid down in art 34 TEU (pre-Lisbon) was almost identical to the definition of directives in the then art 249 EC Treaty. Framework decisions have been removed from the catalogue of secondary legislation as of the entry into force of the Treaty of Lisbon, although those adopted before 1 December 2009 will remain in force until they are repealed, annulled or amended (see art 9 of the Protocol 36 to the Founding Treaties).

52 In accordance with art 52 of the Act, the texts of the acts of the EU institutions adopted before accession and drawn up by these institutions in the Croatian language shall, as of the date of accession, be authentic under the same conditions as the texts drawn up in the other official languages of the European Union and they shall be published in the OJ.

53 One should not expect the extreme scenario known from the accession of Malta when for the first three years of membership even some of the post-accession legislation was not published in Maltese. See Council Regulation (EC) 930/2004 of 1 May 2004 on temporary derogation measures relating to the drafting in Maltese of the acts of the institutions of the European Union [2004] OJ L169/1.
} 
Although the first issues of the Special Edition of the Official Journal in Croatian were available when this article went to print, it was still unknown what percentage of EU legal acts would not make it to the voluminous OJ before 1 July 2013 (or any later date of accession). ${ }^{54}$ Any delays in publication, particularly in relation to EU regulations, would undermine the effectiveness and enforcement of EU law in Croatia. As known from the case law of the Court of Justice, such unpublished legal acts cannot be invoked by the state authorities against individuals, even when the actions of the latter amount to circumvention or breach of EU law. This univocal conclusion stems from case C-161/06 Skoma-Lux and has been widely followed not only by the courts of eight Central and Eastern European countries that joined the European Union in 2004 but also by the Bulgarian and Romanian judiciaries. ${ }^{55}$ The availability of the translated and published acquis is one side of the coin, the quality of translation is the other. It is no secret that this was one of challenges of the past enlargement rounds, particularly in the wake of the two recent waves of enlargement. The fairly obvious, although not easily noticeable, mistakes in translation led to litigation at domestic level ${ }^{56}$ and even reached the Court of Justice. ${ }^{57}$ This is also likely to be the case with Croatia. The translation of pre-accession case law is equally important, although it was neglected during the fifth and sixth enlargement rounds. Alas, only a handful of the evergreens was translated and made available on the website of the Court of Justice. Taking into account the limited language skills of judges in Central and Eastern Europe, the discussed lack of translated judgments has been a serious yet overlooked problem, affecting the enforcement of EU law. ${ }^{58}$ In reality, only post-accession case law has been translated without major delays into the languages of the new Member States. Arguably, similar problems may arise with the Croatian accession. It goes without saying that post-accession case law will

\footnotetext{
54 In the case of Bulgaria and Romania, the number of translated legal acts on the date of accession was $51 \%$ and $46 \%$ (respectively). See further Łazowski (n 8) 420.

55 See, inter alia, M Bobek, 'The Binding Force of Babel: The Enforcement of EC Law Unpublished in the Languages of the New Member States' (2006-07) 9 Cambridge Yearbook of European Legal Studies 43; K Lasińki-Sulecki and W Morawski, 'Late Publication of EC Law in Languages of New Member States and its Effects: Obligations on Individuals Following the Court's Judgment in Skoma-Lux' (2008) 45 CML Rev 705.

56 Examples from Poland are discussed in A Łazowski, Half Full and Half Empty Glass: The Application of EU Law in Poland (2004-2010)' (2011) 48 CML Rev 503, 522. More examples in M Bobek, 'The New European Judges and the Limits of the Possible' in Lazowski (n 19).

57 Case C-63/06 UAB Profisa v Muitinés departamentas prie Lietuvos Respublikos finansu ministerijos [2007] ECR I-3239.

58 See an excellent account of consequences in U Jaremba, 'Polish Civil Judges as European Union Law Judges: Knowledge, Experiences and Attitudes' (doctoral thesis, Erasmus University Rotterdam 2012) <http://repub.eur.nl/res/pub/37318/Manuscript-Jaremba\%20-FINAL-september-2012.pdf> accessed 10 November 2012.
} 
be translated into Croatian almost from the first days of membership in the European Union.

The availability of translated legislation and case law is one potential challenge on the way to the smooth and effective application of EU law. Another prerequisite is the willingness and ability of Croatian judges to give effect to the incoming tide of EU law. The key question remains to what extent Croatian judges will be happy to become EU law judges, as required by the case law of the Court of Justice. One needs a crystal ball to make any such predictions, yet some conclusions can be drawn from the experience gained in Central and Eastern European countries. Although each and every country has its own specificity, certain general patterns have emerged over the last decade. The first wave of EU law related cases to reach the domestic courts touched upon customs and VAT taxation. ${ }^{59}$ Such cases largely had a factual background locked in the pre-accession phase, thus EU law was not applicable. However, some judges were willing to use it as a point of reference in the difficult task of interpretation of domestic law. It is notable that even if such domestic courts had serious doubts as to the interpretation of EU legislation, they had no jurisdiction to proceed with reference for a preliminary ruling to the Court of Justice. The latter, rather boldly, held in case C-302/04 Ynos that it could not offer any assistance to domestic judges. ${ }^{60}$ This wave of cases was soon followed by the first examples of fully fledged EU law based litigation that really tested the ability of domestic courts to give effect to EU law. The same is likely to happen in Croatia. Providing the admissibility criteria are fulfilled, Croatian judges will have the jurisdiction to send references for a preliminary ruling to the Court of Justice as per article 267 TFEU. It is questionable whether this jurisdiction will extent to the measures that had been adopted before the entry into force of the Treaty of Lisbon in the former Third Pillar (Police and Judicial Cooperation in Criminal Matters). The former article 35 TEU, dealing with the jurisdiction of the Court of Justice in that area, has been repealed by the Treaty of Lisbon. Hence, it is assumed that as of 1 December 2009 the Member States cannot opt-in and recognise the jurisdiction. This remains of relevance until 1 December 2014 when the Court of Justice will receive full jurisdiction and all references for preliminary ruling touching upon the former Third Pillar legislation will be covered by the general regime laid down in article 267 TFEU.

\footnotetext{
59 See country chapters in Łazowski (n 19).

60 Case C-302/04 Ynos kft v Jànos Varga, [2006] ECR I-390. See further, N Półtorak, 'Ratione Temporis Application of the Preliminary Rulings Procedure' (2008) 45 CML Rev 1357.
} 


\section{Adaptations to the existing EU acquis and transitional periods}

\subsection{Permanent adaptations to the EU acquis}

The accession of countries to the European Union has profound consequences for the legal order of the European Union and requires technical adaptations to the existing acquis. Adjustments to the Founding Treaties chiefly deal with the institutional provisions discussed above. However, there are also a modest number of substantive amendments. Firstly, article 12 of the Act amends article 64(1) TFEU on free movement of capital. The latter provides for a cut-off date for restrictions applied to free movement of capital and payments with third countries. As much as article 63 TFEU envisages free movement rules in this respect, the Member States are allowed to maintain restrictions that existed on 31 December 1993 as per domestic or EU law. ${ }^{61}$ For Bulgaria, Estonia and Hungary, this date is 31 December 1999 and for Croatia, in accordance with the discussed article 12 of the Act, it is going to be 31 December 2002. Further substantive modifications to the TEU and EAEC concern the territorial application of the Founding Treaties and the language versions of the Treaties. Articles 13-15 of the Act amend articles 52(1), 55(1) TEU and article 225 EAEC to take into account the accession of Croatia.

Permanent adaptations to the secondary legislation adopted by the European Union before the cut-off date in the accession negotiations (1 July 2011) are provided in Annex III and Annex IV of the Act. The first includes amendments to the EU acquis on recognition of qualifications, ${ }^{62}$ intellectual property rights, ${ }^{63}$ financial services, ${ }^{64}$ agriculture, ${ }^{65}$ fisher-

${ }_{61}$ See, inter alia, Case C-157/05 Holböck v Finanzamt Salzburg-Land [2007] ECR I-4051.

62 Parliament and Council Directive 2005/36/EC of 7 September 2005 on the recognition of professional qualifications [2005] OJ L255/22.

63 Parliament and Council Regulation (EC) 1610/96 of 23 July 1996 concerning the creation of a supplementary protection certificate for plant protection products [1996] OJ L198/30; Council Regulation (EC) 6/2002 of 12 December 2001 on Community designs [2002] OJ L3/1; Council Regulation (EC) 207/2009 of 26 February 2009 on the Community trade mark [2009] OJ L78/1; European Parliament and Council Regulation (EC) 469/2009 of 6 May 2009 concerning the supplementary protection certificate for medicinal products [2009] OJ L152/1.

64 Parliament and Council Directive 2006/48/EC of 14 June 2006 relating to the taking up and pursuit of the business of credit institutions [2006] OJ L177/1.

65 Council Regulation (EC) 1601/91 of 10 June 1991 laying down general rules on the definition, description and presentation of aromatized wines, aromatized wine-based drinks and aromatized wine-product cocktails [1991] OJ L149/1; Council Regulation (EC) 1234/2007 of 22 October 2007 establishing a common organisation of agricultural markets and on specific provisions for certain agricultural products (Single CMO Regulation) [2007] OJ L299/1; Parliament and Council Regulation 110/2008 of 15 January 2008 on the definition, description, presentation, labelling and the protection of geographical indications of spirit drinks [2008] OJ L39/16; Council Regulation (EC) 73/2009 of 19 January 2009 establishing common rules for direct support schemes for farmers under the common 
ies, ${ }^{66}$ taxation, ${ }^{67}$ regional policy and coordination of structural instruments, ${ }^{68}$ and environmental protection. ${ }^{69}$ The second contains a number of permanent provisions determining the application of the selected EU rules on intellectual property rights, ${ }^{70}$ competition policy, ${ }^{71}$ agriculture ${ }^{72}$ and fisheries, ${ }^{73}$ as well as customs union. ${ }^{74}$

\subsection{Transitional periods provided in the Seventh Accession Treaty}

Transitional periods became a standard feature of the EC/EU accession process with the first enlargement of the European Communities in 1973; however, their form and scope evolved in the subsequent enlargement rounds. ${ }^{75}$ The accession of Croatia is no exception, hence

agricultural policy and establishing certain support schemes for farmers [2009] OJ L30/16. Amendments to the latter Regulation are of particular importance as they provide the phasing in of direct payments for Croatian farmers.

66 Council Regulation (EC) 2371/2002 of 20 December 2002 on the conservation and sustainable exploitation of fisheries resources under the Common Fisheries Policy [2002] OJ L358/59; Council Regulation (EC) 1198/2006 of 27 July 2006 on the European Fisheries Fund [2006] OJ L223/1.

67 Council Directive 2006/112/EC of 28 November 2006 on the common system of value added tax [2006] OJ L347/1; Council Directive 2008/118/EC of 16 December 2008 concerning the general arrangements for excise duty [2009] OJ L9/12.

68 Council Regulation (EC) 1083/2006 of 11 July 2006 laying down general provisions on the European Regional Development Fund, the European Social Fund and the Cohesion Fund [2006] OJ L2 10/25.

69 Parliament and Council Directive 2003/87/EC of 13 October 2003 establishing a scheme for greenhouse emission allowance trading within the Community [2003] OJ L275/32.

70 A specific mechanism is provided for holders or the holder's beneficiaries of patents or Supplementary Protection Certificates for medicinal products. If they were filed in a Member State at the time when such protection could not be obtained in Croatia for a particular product, then holders or the holder's beneficiaries may rely on the rights granted by that patent or SPC in order to prevent the import and marketing of that product in the Member State or Member States where the product in question enjoys patent or SPC protection. This is even if this product was put on the market in Croatia for the first time by the holder or with the holder's consent. Any person intending to import or market a medicinal product covered by the above rules in a Member State where the product enjoys patent or SPC protection shall demonstrate to the competent authorities in the application regarding that import that one month's prior notification has been given to the holder or beneficiary of such protection.

${ }^{71}$ Annex IV provides tailor-made rules on existing state aid programmes implemented in Croatia.

72 Annex IV deals with the public and private stocks of agricultural products held at the day of accession to the European Union.

73 Annex IV covers state aid granted in the area of fisheries.

74 Annex IV contains a number of tailor-made rules on, inter alia, the proof of Union status, the proof of preferential origin and customs procedures.

75 See, inter alia, K Inglis, 'The Accession Treaty and its Transitional Arrangements: A Twilight Zone for the New Members of the Union' in Ch Hillion (ed), EU Enlargement: A Legal Approach (Hart Publishing 2004). 
the Seventh Accession Treaty provides for a number of transitional provisions. Traditionally, some of the transitional periods were negotiated on the initiative of the European Union and some on the request of an acceding country. In the case of Croatia, in a few negotiating chapters, the transitional periods were modelled on the previous two Accession Treaties (free movement of workers and free movement of capital), in other areas they are a unique feature of the seventh enlargement.

\subsubsection{Free movement of workers (including posting of workers)}

Free movement of workers traditionally belongs to areas of particular interest to the candidate countries. In the perception of the general public, it is the key element that makes EU integration particularly attractive and renders the pre-accession effort worthwhile. The Stabilisation and Association Agreement with Croatia ${ }^{76}$ contains, similarly to the Europe Agreements, ${ }^{77}$ rather restrictive provisions in this respect, granting non-discriminatory treatment to Croatian nationals admitted legally to the labour markets of the EU Member States. ${ }^{78}$ Access to the labour markets remains in the hands of the legislators within the EU Member States, not only until the date of accession but also, as will be

76 Stabilisation and Association Agreement between the European Communities and their Member States, of the one part, and the Republic of Croatia, of the other part [2005] OJ L26/3.

77 Europe Agreement establishing an association between the European Communities and their Member States, of the one part, and the Republic of Poland, of the other part [1993] OJ L348/2; Europe Agreement establishing an association between the European Communities and their Member States, of the one part, and the Republic of Hungary, of the other part [1993] OJ L347/2; Europe Agreement establishing an association between the European Communities and their Member States, of the one part, and the Czech Republic, of the other part [1994] OJ L360/2; Europe Agreement establishing an association between the European Communities and their Member States, of the one part, and the Slovak Republic, of the other part [1994] OJ L359/2; Europe Agreement establishing an association between the European Communities and their Member States, of the one part, and Romania, of the other part [1994] OJ L357/2; Europe Agreement establishing an association between the European Communities and their Member States, of the one part, and the Republic of Bulgaria, of the other part [1994] OJ L358/3; Europe Agreement establishing an association between the European Communities and their Member States, of the one part, and the Republic of Lithuania, of the other part [1998] OJ L51/3; Europe Agreement establishing an association between the European Communities and their Member States, of the one part, and the Republic of Latvia, of the other part [1998] OJ L26/3; Europe Agreement establishing an association between the European Communities and their Member States, of the one part, and the Republic of Estonia, of the other part [1998] OJ L68/3; Europe Agreement establishing an association between the European Communities and their Member States, acting within the framework of the European Union, of the one part, and the Republic of Slovenia, of the other part [1999] OJ L51/3. For an in-depth commentary, see A Ott and K Inglis (eds), Handbook on European Enlargement: A Commentary on the Enlargement Process (TMC Asser Press 2002).

78 For comparative analysis, see I Goldner Lang, From Association to Accession: How Free is the Free Movement of Persons in the EU (Eleven International Publishing 2011) 61-65. 
explained below, during the transitional period laid down in Section 2 of Annex V to the Seventh Accession Treaty. It did not come as a surprise that Croatia declared its readiness to apply the EU acquis in Chapter 2 (Free movement of persons) upon accession and therefore did not request transitional periods. It was the European Union that had an interest in imposing transitional arrangements, only gradually allowing Croatian nationals access to the labour markets of its Member States. The negotiating position, as well as the final arrangement, follows the $2+3+2$ year model, which was also applied to other countries of Central and Eastern Europe. ${ }^{79}$ It allows the existing Member States, as well as Croatia, to impose restrictions to free movement of workers for a maximum of seven years after accession. As a general principle, the restrictions allowed under the Seventh Accession Treaty may not result in conditions for the access of Croatian nationals to the labour markets of the present Member States which are more restrictive than those prevailing on the date of signature of the Accession Treaty. ${ }^{80}$

The transitional regime that will apply as of the date of accession is as follows. By way of derogation from articles 1-6 of Regulation 492/2011/ $\mathrm{EU},{ }^{81}$ the Member States are allowed to apply domestic law restricting access to their labour markets for an initial period of two years following Croatia's accession to the European Union. ${ }^{82}$ The existing system will be reviewed after two years from the date of Croatia's accession. At that point, the Member States may declare a desire to continue the application of the transitional periods for another three years or, as an alternative, start the application of articles 1-6 of Regulation 492/2011/EU. It should be noted that no justification for the extension of restrictions is required by the Accession Treaty. The only obligation that the Member States have to comply with is laid down in Section 2.3 of Annex V to the Accession Treaty, mainly that Member States should notify their intentions to the European Commission. Failure to notify would amount to tacit approval of the application of articles 1-6 of Regulation 492/2011/

\footnotetext{
79 See further, inter alia, M Dougan, 'A Spectre is Haunting Europe: Free Movement of Persons and the Eastern Enlargement' in Hillion (n 75); K Kowalik-Bańczyk, 'Polish Transitional Periods Relating to Four Freedoms - Temporary Derogations' (2004-05) 27 Polish Yearbook of International Law 184.

80 Section 2.13 of Annex V to the Seventh Accession Treaty.

81 Parliament and Council Regulation (EU) 492/2011 of 5 April 2011 on freedom of movement for workers within the Union [2011] OJ L141/1.

82 Some of the Western European countries have already declared the willingness to do so. In relation to the United Kingdom, see Home Office Network, 'Statement of Intent: Accession of Croatia to the European Union: Transitional Restrictions on Labour Market Access' (October 2012)

<http://www.homeoffice.gov.uk/publications/immigration/croatia-eu-accession/statement-of-intent?view=Binary $>$ accessed 10 November 2012.
} 
EU. The final review of the transitional regime will come five years after the enlargement. The Member States will be allowed to maintain the restrictions for another two years, this time, however, only in the case of serious disturbances on the labour market, or threats thereof. Again, notification of the European Commission is a conditio sine qua non.

It merits attention that the above regime is not compulsory; therefore, the Member States are free to open their labour markets to Croatian citizens as of the date of accession. It is notable, however, that during the initial period of two years after accession such access to the labour markets may only be provided under the domestic law of the Member States. Regulation 492/2011/EU may only apply to Croatian migrating citizens as of the third year of membership. One should also add that for a period of seven years following accession, the Member States may exceptionally impose restrictions in the case of existing or foreseeable serious disturbances on the labour market (that 'could seriously threaten the standard of living or level of employment in a given region or occupation'). In order to make this possible, a special procedure was tailored and inserted into the Seventh Accession Treaty. ${ }^{83}$

The Seventh Accession Treaty also provides rules applicable to Croatian citizens who are already residing and legally employed in the Member States of the European Union. For instance, those who have met the above criteria for an uninterrupted period of 12 months or longer will enjoy access to the labour market of that particular Member State. At the same time, they will not benefit from free movement rights per se as their residence rights are limited to the host country only. Furthermore, the Accession Treaty also provides for a special regime applicable to family members of Croatian workers. ${ }^{84}$

\footnotetext{
83 In accordance with Section 2.7 of Annex V to the Accession Treaty, when a Member State, which lifted the restrictions and applies arts 1-6 of Regulation 492/2011/EU, undergoes or foresees disturbances on its labour market which could seriously threaten the standard of living or level of employment in a given region or occupation, it shall inform the European Commission and the other Member States thereof and shall supply them with all relevant particulars. On the basis of this information, the Member State may request the European Commission to state that the application of arts 1 to 6 of Regulation 492/2011/ EU is wholly or partially suspended in order to restore to normal the situation in that region or occupation. The European Commission shall decide on the suspension and on the duration and scope thereof no later than two weeks after receiving such a request and shall notify the Council of the European Union of its decision. Any Member State may, within two weeks of the European Commission's decision, request the Council of the European Union to annul or amend that decision. The Council of the European Union shall act on such a request within two weeks, by qualified majority. It is notable that in urgent and exceptional cases, a Member State may suspend the application of arts 1 to 6 of Regulation 492/2011/ EU, followed by a reasoned ex post notification to the Commission.
}

84 See sections 2.2 and 2.8 of Annex V to the Accession Treaty. 
One should note that the discussed transitional regime is limited only to free movement of workers, so Croatian nationals who meet the criteria for other types of residence laid down in articles 6 and 7 of Directive 2004/38/EC ${ }^{85}$ will benefit from movement rights as of the date of accession. This includes Croatian nationals who reside in the Member States for up to three months or as self-employed (the right of establishment), students, pensioners and the lucky ones with financial resources. Furthermore, there are no general restrictions in relation to the free movement of services (article 56 TFEU). However, there is one tailor-made exception in this respect which merits attention. Mainly, in order to placate serious concerns on the part of Germany and Austria, special derogations have been allowed in relation to the free movement of selected types of services provided by companies established in Croatia. ${ }^{86}$ In the case of Germany, the list includes construction services as well as industrial cleaning and the activities of interior decorators. The Austrian list is much longer, running from horticultural service activities to construction and security services. The restrictions can be maintained as long as both countries apply the derogations to articles 1-6 of Regulation 492/2011/EU.

Last, one should consider the impact of the transitional period on free movement of workers on the eligibility of Croatian citizens to acquire the permanent right to reside. The latter is laid down in article 16 of Directive 2004/38/EC and requires five years of lawful and uninterrupted residence. In a controversial judgment in joined cases C-424/10 and C-425/10 Szeja \& Zió kowski, ${ }^{87}$ the Court of Justice clarified that lawful residence must be in accordance with EU law; a contrario, periods of lawful residence (however long) based on the domestic law of the Member States do not constitute qualifying periods. This triggers a pertinent question about whether or not Croatian citizens, who already reside in the Member States or will do so on the basis of domestic immigration laws upon accession, would benefit from the right in question. In fact, the principle laid down in Szeja \& Zió kowski may come to the rescue as it can be easily applied mutatis mutandis to Croatian citizens. According to the Court of Justice, periods of residence pre-dating accession to the European Union can be considered as qualifying periods for the right of

\footnotetext{
85 Parliament and Council Directive 2004/38/EC of 29 April 2004 on the right of citizens of the Union and their family members to move and reside freely within the territory of the Member States amending Regulation (EEC) No 1612/68 and repealing Directives 64/221/ EEC, 68/360/ EEC, 72/194/EEC, 73/148/EEC, 75/34/EEC, 75/35/EEC, 90/364/EEC, 90/365/EEC and 93/96/EEC [2004] OJ L158/77.

86 See section 2.12 of Annex V to the Accession Treaty.

87 Joined Cases C-424 and 425/10 Tomasz Zió kowski and Barbara Szeja and Others $v$ Land Berlin (ECR, 21 December 2011).
} 
permanent residence as long as the citizens of the newcomers met the criteria laid down in EU law. This, of course, is a legal fiction, as prior to accession EU free movement rules do not - as a matter of principle - apply to citizens of third countries (candidate and acceding countries included). Still, the Court of Justice decided in Szeja \& Zió kowski to present citizens of the new Member States with this 'welcome' gift. Consequently, Croatian citizens who, by the time of accession, have resided in the new Member States for periods of five years or more and were workers/selfemployed, etc, will benefit from the permanent right to reside and all resulting benefits. This means that the criteria for residence laid down in article 7 of Directive 2004/38/EC will not apply and, at the same time, Croatian citizens will benefit, inter alia, from the enhanced protection against expulsion provided in article 28 of that Directive.

\subsubsection{Free movement of capital}

As much as restrictions to free movement of workers are traditionally requested by the old Member States, transitional periods regarding land and property ownership are a spécialité de la maison of the newcomers. Croatia is no exception, although the transitional regime is more modest when compared with the Fifth and Sixth Accession Treaties. ${ }^{88}$ As per Section 3 of Annex V to the Accession Treaty, Croatia may maintain in force for seven years from the date of accession the restrictions laid down in its Agricultural Land Act, ${ }^{89}$ as in force on the date of signature of the Seventh Accession Treaty. ${ }^{90}$ This applies only to the acquisition of agricultural land by nationals of another Member States of the European Union, EEA-EFTA countries, and legal persons formed in accordance with their laws. However, a national of a Member State (and

\footnotetext{
88 For instance, the Accession Treaty 2005 provided for two transitional periods with regard to the acquisition of secondary residences and the acquisition of agricultural land, forests and forestry land. In the case of the former, Bulgaria and Romania were allowed to maintain the restrictions for five years from the date of accession. This applied to the acquisition of land for secondary residences by nationals of the European Union or EFTA-EEA countries who were non-resident in Bulgaria or Romania, as well as legal persons formed in accordance with EU/EEA Member State law. The latter allowed the maintenance of the existing restrictions that applied to nationals of EU/EFTA-EEA countries as well as legal persons established there for seven years following the date of accession. These restrictions did not apply to self-employed farmers who expressed a wish to establish themselves and reside in Bulgaria or Romania.

89 Zakon o poljoprivrednom zemljištu (Narodne novine, br. 152/08, 25/09, 153/09, 21/10, $90 / 10,124 / 10,39 / 11,61 / 11)$

90 In accordance with section 3 of Annex $\mathrm{V}$ to the Accession Treaty a general review of this transitional regime shall be held by the end of the third year following the date of accession. The following modus operandi will apply: the European Commission will submit a report to the Council of the European Union. The latter may, acting unanimously on a proposal from the European Commission, decide to shorten or terminate the transitional period.
} 
accordingly a legal person formed in accordance with the laws of another Member State) may not be treated less favourably in respect of the acquisition of agricultural land than such a national or person would have been treated at the date of signature of the Seventh Accession Treaty, or may not be treated in a more restrictive way than a national or a legal person of a third country. It is notable that self-employed farmers, who are nationals of another Member State and who wish to establish themselves and reside in Croatia, will not be subject to the provisions of the first paragraph or to any rules and procedures other than those to which nationals of Croatia are subject.

The Accession Treaty provides an option for an exceptional extension of the discussed transitional regime. In the case of sufficient evidence that, upon the expiry of the seven year transitional period, there will be serious disturbances or a threat of serious disturbances to Croatia's agricultural land market, Croatia may submit a request to this end to the European Commission. The latter may decide to extend the transitional period for another three years, although subject to the caveat that this extension may be limited to selected geographical areas particularly affected.

\subsubsection{An overview of transitional periods in other areas of EU law}

The Seventh Accession Treaty also provides for transitional periods in other areas of law, although many of them are of a very technical and rather low profile nature. Hence, they will be briefly covered in this section of the article. ${ }^{91}$ To start with, there are a number of transitional arrangements applicable to the agriculture acquis. ${ }^{92}$ This includes rules on the direct support schemes for farmers and a transitional tariff quota for raw cane sugar for refining. Furthermore, the Seventh Accession Treaty also provides for a number of transitional rules applicable to legislation on food safety and veterinary and phytosanitary policy. ${ }^{93}$ For instance, Croatian hens in lay on the date of accession will have to bear for an extra year after accession with cages that do not comply with Directive 1999/74/EC on minimum standards for the protection of laying hens. ${ }^{94}$ A tailor-made regime is also provided for establishments producing meat,

\footnotetext{
91 For a more comprehensive analysis, see Delegation of the European Union to the Republic of Croatia Network, 'Information on the Results of the EU Accession Negotiations with Croatia' (November 2011), <http://www.delhrv.ec.europa.eu/files/file/articlesCopy\%20of\%20results_of_th_eu_accession_negotiations_with_croatia-1322673321.pdf> accessed 10 November 2012.

92 See section 4 of Annex V to the Accession Treaty.

93 See section 5 of Annex V to the Accession Treaty.

94 Council Directive 1999/74/EC of 19 July 1999 laying down minimum standards for the protection of laying hens [1999] OJ L203/53.
} 
milk, fish and animal by-products. A temporal waiver of the application of structural requirements laid down in the Regulation 852/2004/EC on the hygiene of foodstuffs ${ }^{95}$ may be a good example. These rules will not apply to selected establishments in Croatia until 31 December 2015. ${ }^{96}$ This, of course, comes at the price of an export ban to the European Union. As per Section 5.2 of Annex V to the Accession Treaty, as long as such establishments benefit from the waiver, their products shall only be placed on the Croatian market or on markets of third countries in accordance with relevant EU legislation.

Another area where transitional regime will apply is fisheries. In accordance with Section 6 of Annex V to the Accession Treaty, short derogations are available to Croatia from the legal regime established by Regulation 1967/2006/EC on sustainable exploitation of fishery resources in the Mediterranean Sea. ${ }^{97}$ Relatively short derogations are also provided in transport (section 7 of Annex $\mathrm{V}$ to the Accession Treaty) ${ }^{98}$ and taxation areas (section 8 of Annex $\mathrm{V}$ to the Accession Treaty). ${ }^{99} \mathrm{~A}$ transitional arrangement is also provided for border checks at the border crossing points with Bosnia and Herzegovina. ${ }^{100}$

95 Parliament and Council Regulation (EC) 852/2004 of 29 April 2004 on the hygiene of foodstuffs [2004] OJ L139/1.

96 A list of the establishments covered by this regime is expected to be produced by the European Commission "in good time before the accession". See section 5.6 of Annex V to the Accession Treaty.

97 Council Regulation (EC) 1967/2006 of 21 December 2006 concerning management measures for the sustainable exploitation of fishery resources in the Mediterranean Sea, amending Regulation (EEC) No 2847/93 and repealing Regulation (EC) No 1626/94 [2006] OJ L409/11.

98 The transitional regime applies to both maritime cabotage and road haulage market (see, respectively, Council Regulation (EEC) 3577/92 of 7 December 1992 applying the principle of freedom to provide services to maritime transport within Member States [1992] OJ L364/7 and Parliament and Council Regulation (EC) 1072/2009 of 21 October 2009 on common rules for access to the international road haulage market [2009] OJ L300/72).

99 The first derogation affects the legislation on taxation of cigarettes. Interestingly enough, section 8 of Annex V to the Accession Treaty refers to Council Directive 92/79/EEC of 19 October 1992 on the approximation of taxes on cigarettes [1992] OJ L316/8 which at the time of signature of the Seventh Accession Treaty was no longer in force (sic!). It has been replaced by Council Directive 2011/64/EU of 21 June 2011 on the structure and rates of excise duty applied to manufactured tobacco [2011] OJ L176/24. However, it is legitimate to assume that the transitional regime will apply mutatis mutandis to the new legislation. Further temporal derogations in this chapter apply to Council Directive 2006/112/EEC of 28 November 2006 on the common system of value added tax [2006] OJ L347/1.

100 To this end, art 19a is inserted by means of the Accession Treaty to the European Parliament and Council Regulation (EC) of 15 March 2006 establishing a Community Code on the rules governing the movement of persons across borders (Schengen Border Code) [2006] OJ L105/1. 
As with previous accession rounds, several long transitional periods have been negotiated in the environmental area. This is not surprising, taking into account the complexity and the economic impact the transposition of the EU acquis may have in this area. Some of the transitional arrangements will remain for as long as 10 years after accession. They include EU horizontal legislation, ${ }^{101}$ as well as the EU acquis on air quality, ${ }^{102}$ waste management, ${ }^{103}$ water quality, ${ }^{104}$ integrated pollution prevention and control ${ }^{105}$ and, last, chemicals. ${ }^{106}$

\subsection{Additional transitional periods negotiated after the signature of the Accession Treaty 2011}

With the completion of accession negotiations and signature of the accession treaty, an important part of rapprochement comes to an end. However, the EU decision-making machinery moves on, resulting in the adoption of new legislation on a very regular basis. This has particular implications for an acceding country and its obligations. In the case of Croatia, the cut-off date was 1 July 2011, therefore any EU legislation adopted after that date was not covered by the negotiations exercise. Bearing this in mind, the drafters of the Seventh Accession Treaty provided a tailor-made procedure which can be employed should the Croatian authorities express a desire to benefit from a transitional period related to the EU acquis adopted in the period between 1 July 2011 and the date of accession. In accordance with article 49 of the Act, at a duly substantiated request of Croatia, submitted to the European Commission no later than the date of accession, the Council of the European Union, acting on a proposal from the Commission, or the European Commission, if the original act was adopted by it, may take measures consisting of tempo-

\footnotetext{
101 The transitional regime covers, for instance, Parliament and Council Directive 2003/87/ EC of 13 October 2003 establishing a scheme for greenhouse gas emission allowance trading within the Community and amending Council Directive 96/61/EC [2003] OJ L275/32.

102 The transitional regime applies to Parliament and Council Directive 2008/50/EC of 21 May 2008 on ambient air quality and cleaner air for Europe [2008] OJ L152/1.

103 The transitional regime applies to Council Directive 1999/31/EC of 26 April 1999 on the landfill of waste [1999] OJ L182/1.

104 The transitional regime applies, inter alia, to Council Directive 91/271/EEC of 21 May 1991 concerning urban waste-water treatment [1991] OJ L135/40.

105 The transitional regime applies, inter alia, to Council Directive 1999/13/EC of 11 March 1999 on the limitation of emissions of volatile organic compounds due to the use of organic solvents in certain activities and installations [1999] OJ L85/1.

106 The transitional rules apply to Parliament and Council Regulation (EC) 1907/2006 of 18 December 2006 concerning the Registration, Evaluation, Authorisation and Restriction of Chemicals (REACH), establishing a European Chemicals Agency, amending Directive 1999/45/EC and repealing Council Regulation (EEC) No 793/93 and Commission Regulation (EC) No 1488/94 as well as Council Directive 76/769/EEC and Commission Directives 91/155/EEC, 93/67/EEC, 93/105/EC and 2000/21/EC [2006] OJ L396/1.
} 
rary derogations from such secondary legislation. Where these derogations are adopted after the accession of Croatia to the European Union, they may be applied as of the date of accession. One should note the importance of the Information and Consultation Procedure discussed above. As already argued, it allows the Croatian authorities to be consulted on the pending proposals and, by the same token, prepare requests for such additional transitional periods.

\section{Impact of the accession on Croatia's and the European Union's international obligations}

Over the years, the European Communities and then also the European Union have evolved into important international actors. This translates into a web of international agreements concluded by the European Union with countries on all continents and with international organisations. It comes from this that the accession of Croatia has crucial political and legal consequences for the European Union's external relations. It moves the EU borders further down to the south east of the Balkans region and increases the EU presence in the Mediterranean. The legal consequences of the seventh enlargement for relations with third countries and international organisations are thoroughly regulated in article 6 of the Act. It should be emphasised that the rules on the adherence to international treaties to which the European Union and the European Atomic Energy Community are a party mirror the arrangements known from the Accession Treaties 2003 and 2005. ${ }^{107}$

As a general rule, agreements and conventions concluded by the European Union ${ }^{108}$ are binding on Croatia and it has the obligation to adhere to them. ${ }^{109}$ Croatia's adherence to these international treaties is regulated in separate protocols, negotiated by the European Commission and concluded by the Council of the European Union. The EU-Swiss Agreement on Free Movement of Persons is excluded and negotiations of a tailor-made protocol will be required. ${ }^{110}$ Under the terms of article

\footnotetext{
107 For a legal appraisal of the latter, see Inglis (n 8) 940-945 and Lazowski (n 8) 428429.

108 This includes agreements concluded by the European Community before the entry into force of the Treaty of Lisbon. As per art 1 TEU, the European Union is a successor of the European Community and this includes the external obligations of the latter.

109 Detailed rules on agreements on textiles, steel and steel products as well as fisheries are contained in art 6(6-8) of the Act.

110 Agreement between the European Community and its Member States, of the one part, and the Swiss Confederation, of the other, on the free movement of persons [2002] OJ L114/6.
} 
6(4) of the Act, Croatia accedes to the Cotonou Agreement. ${ }^{111}$ Moreover, Croatia has the obligation to accede to the European Economic Area. It is notable that the obligation stemming from article 6(5) of the Act merely reproduces provisions of the Agreement on the European Economic Area. ${ }^{12}$ One should note that the accession of Croatia to the EEA will be regulated by a different agreement from that governing its accession to the EU.

Accession to the European Union also has pivotal consequences for the newcomers' external obligations. For example, Croatia has the obligation to withdraw from free trade agreements with third countries (including the CEFTA Agreement) and to adjust other international commitments to the requirements of membership. Both obligations are laid down in a rather univocal manner in article 6 (9) of the Act.

\section{Pre- and post-accession conditionality - the safeguard clauses}

\subsection{Conditionality, benchmarking and compliance with the EU acquis}

The compliance of the new Member States with the EU membership criteria has been the subject of constant debate ever since the biggest enlargement project was launched in the early 1990s. The specificity of the newly established democracies in Central and Eastern Europe as well as the countries established on the ashes of former Yugoslavia forced the European Union to develop an unprecedented pre-accession policy. No previous enlargement round required such an effort from the European Union itself. Despite this, as the sixth enlargement proves, all the assistance, conditionality, and benchmarking combined with the political pledge as to future enlargements are not strong enough to serve as catalysts for deep and comprehensive reforms in some of the new Member States as well as candidate and potential candidate countries. As already noted, for Bulgaria and Romania, the Accession Treaty 2005 even contained a membership postponement safeguard clause. Furthermore, the European Commission designed a tailor-made Co-operation and Verification Mechanism aimed at post-accession monitoring of compliance with several threshold criteria. ${ }^{113}$ Alas, the latter is not a suc-

\footnotetext{
111 Partnership Agreement between the members of the African, Caribbean and Pacific Group of States on the one part, and the European Community and its Member States, of the other part [2000] OJ L317/3.

112 Art 128 of the EEA Agreement (Agreement on the European Economic Area) [1994] OJ $\mathrm{L} 1 / 1$.

113 Commission Decision 2006/928/EC of 13 December 2006 establishing a mechanism for co- operation and verification of progress in Romania to address specific benchmarks in the areas of judicial reform and the fight against corruption [2006] OJ L354/56; Commis-
} 
cess story and almost six years after the accession the end is nowhere near. ${ }^{114}$ This experience inspired the European Union to develop further the pre-accession instruments and forced it to look for other means of maintaining the enlargement momentum and, at the same time, keeping the constant pressure on the potential candidates and, even more so, on the candidate countries. Croatia is the first to experience this new accession reality where rapprochement is based on much stricter conditionality and benchmarking, particularly (but not only) in the area of judiciary and fundamental rights. To this end, a special monitoring mechanism is provided in article 36 of the Act. As already noted, it became operational on the date of signature of the Accession Treaty. ${ }^{15}$ To include it in the Accession Treaty itself and to make it applicable before accession is an important difference when compared with the pre- and post-accession instruments employed vis-à-vis Bulgaria and Romania. ${ }^{116}$ Alongside this new monitoring mechanism, the Seventh Accession Treaty also provides for a more standard set of safeguard clauses known from the previous Accession Treaties - the economic safeguard clause, the internal market safeguard clause and the JHA safeguard clause. All four instruments are discussed in the next subsections of this article.

\subsection{Monitoring mechanism}

Article 36 of the Act serves as the legal basis for a tailor-made monitoring mechanism allowing the European Union to scrutinise how Croatia complies with the accession commitments. This mechanism allows the European Commission to keep its finger on the political trigger and the Council of the European Union on a 'gun' during the remainder of the pre-accession phase. The key questions are, however, how effective this mechanism will be and, if certain deficiencies in compliance with entry conditions persist, whether the European Union can still employ it when Croatia becomes a Member State. When it comes to the latter, the answer can only be an educated guess. On the one hand, article 36 of the Act is fairly silent on that point. Unlike article 37-39 of the Act, which provide for the three already mentioned safeguard clauses, this provision does not contain any formal time frame. On the other hand,

sion Decision 2006/929/EC of 13 December 2006 establishing a mechanism for cooperation and verification of progress in Bulgaria to address specific benchmarks in the areas of judicial reform and the fight against corruption and organized crime [2006] OJ L354/58.

114 See reports available at: <http://ec.europa.eu/cvm> accessed 10 November 2012.

115 Art 3(5) of the Accession Treaty.

116 See further, inter alia, M Spernbauer, 'Benchmarking, Safeguard Clauses and Verification Mechanisms: What's in a Name? Recent Developments in the Pre-and Post-Accession Conditionality and Compliance with EU Law' (2007) 3 Croatian Yearbook of European Law and Policy 273. 
the existence of these safeguard clauses, combined with the standard enforcement machinery at the disposal of the European Commission (articles 258 and 260 TFEU), make one wonder why the European Union would keep this monitoring tool, which is a political one par excellence, after the accession.

Not surprisingly, the implementation of the monitoring mechanism rests on the shoulders of the European Commission. It has the obligation to 'closely monitor all commitments undertaken by Croatia in the accession negotiations'. This covers the commitments that need to be complied with before or by the date of accession to the European Union, including a set of JHA related commitments laid down in Annex VII to the Accession Treaty ${ }^{117}$ and obligations in respect of state aid to the ship-building industry and the steel sector (Annexes VIII and IX to the Accession Treaty respectively). The tools employed in this exercise include monitoring tables as well as regular dialogue under the SAA, peer assessment missions, the pre-accession economic programme, fiscal notifications and early warning letters to the Croatian authorities. The European Commission also has the obligation to present six-monthly assessments up to the accession on the commitments undertaken by Croatia. However, the main instruments are monitoring reports, the most recent of which was presented on 10 October 2012.

OIt is one thing to introduce a monitoring mechanism, and another thing to enforce the undertaken commitments. Article 36(2) of the Act empowers the Council of the European Union, acting on an initiative of the European Commission, to take appropriate measures. For such

117 The commitments are as follows:

- to continue to ensure effective implementation of its Judicial Reform Strategy and Action Plan;

- to continue to strengthen the independence, accountability, impartiality and professionalism of the judiciary;

- to continue to improve the efficiency of the judiciary;

- to continue to improve the handling of domestic war crimes cases;

- to continue to ensure a sustained track record of substantial results based on efficient, effective and unbiased investigation, prosecution and court rulings in organised crime and corruption cases at all levels including high level corruption, and in vulnerable sectors such as public procurement;

- to continue to improve its track record of strengthened prevention measures in the fight against corruption and conflict of interest;

- to continue to strengthen the protection of minorities, including through effective implementation of the Constitutional Act on the Rights of National Minorities (CARNM);

- to continue to address outstanding refugee return issues;

- to continue to improve the protection of human rights;

- to continue to cooperate fully with the International Criminal Tribunal for the former Yugoslavia. 
measures to be adopted, a qualified majority in the Council is required. The provision in question is rather vague as to the scope and type of measures that can be adopted. Furthermore, as already noted, the time frame is unclear. If the monitoring mechanism is limited to the pre-accession period only, then one would assume that the Council can proceed with the enactment of such measures until the day of accession. However, the question remains if such measures can also be maintained after accession to the European Union. Either way, one would expect such measures to be adopted in a binding form, which, in turn would trigger the jurisdiction of the Court of Justice of the European Union to review the legality as per article 263 TFEU. Annexes VIII and IX providing for specific commitments in the state aid area are far more specific when it comes to sanctions for non-compliance. Mainly, the European Commission has the competence to order the Croatian authorities to recover the granted state-aid.

\subsection{Economic safeguard clause}

The Seventh Accession Treaty also provides for an economic safeguard clause, based on a model used in the previous enlargements. ${ }^{118}$ Under the terms of article 37 of the Act, it can be invoked by Croatia as well as other Member States of the European Union when 'difficulties arise which are serious and liable to persist in any sector of the economy or which could bring about serious deterioration in the economic situation of a given area'. In such a case, any Member State, including Croatia, may apply to the European Commission for an authorisation to take the necessary protective measures. They may involve derogations from the EU Treaty, FEU Treaty as well as the Accession Treaty itself. The economic safeguard clause may be used for a period of up to three years after accession.

\subsection{Internal market safeguard clause}

As already mentioned, article 38 of the Act provides for a unilateral internal market safeguard clause, which may be invoked by the European Union if Croatia 'fails to fulfil commitments undertaken in the context of the accession negotiations'. This includes commitments made in any sectoral policy concerning economic activities with a crossborder effect. It should be noted that the safeguard clause in question may only be employed if the alleged breach of commitments results in a serious breach of the functioning of the internal market or a threat to the Union's financial interests or an imminent risk of such a breach

118 See for instance art 36 of the Act on Conditions of Accession 2005. 
or threat. If that happens, the European Commission may ex officio or upon a reasoned request of a Member State take appropriate measures. Alas, article 38 of the Act is quite vaguely drafted and does not offer interpretation of the term 'measures'. ${ }^{119}$ However, at the same time, it provides some guidelines that should be followed by the European Commission. To start with, such measures have to comply with the wellestablished principle of proportionality. Arguably, the European Commission will have the discretion to determine what is proportionate, yet one should bear in mind that such decisions will fall under the judicial review mechanism laid down in article 263 TFEU. Ultimately, it will be the Court of Justice of the European Union that will be the final arbiter in this respect. Furthermore, article 38 of the Act clarifies that priority shall be given to measures which least disturb the functioning of the internal market and, where appropriate, to the application of the existing sectoral safeguard mechanisms. The competence to invoke the internal market safeguard clause is subject to the following caveat. Safeguard clauses should not be invoked as a means of arbitrary discrimination or a disguised restriction on trade between Member States. The time frame for the use of the internal market safeguard clause also merits attention. As a matter of principle, it is at the disposal of the European Commission for a fixed period of three years after the enlargement but, at the same time, it may be invoked even before accession on the basis of the findings of the monitoring exercise discussed above. If that is the case, then the measures enter into force on the date of accession unless they provide for a later date. Article 38 of the Act clarifies further that the measures shall be maintained no longer than strictly necessary and, in any case, shall be lifted when the relevant commitment has been fulfilled. It is notable that they may be applied beyond a period of three years if the relevant commitments have not been fulfilled. As is well known with the commitments undertaken by the EU newcomers, the carrot and stick principle applies. Thus, article 38 of the Act provides that if Croatia demonstrates progress in fulfilling its commitments, the European Commission may adapt the measures. Not surprisingly, the Member States want to keep a close eye on things, so before the European Commission revokes the safeguard measure it has the obligation to inform the Council of the European Union and 'shall take duly into account any observations of the

\footnotetext{
119 Past experience with similar safeguard clauses laid down in the previous Accession Treaties is not very rich, yet may offer some insights. The internal market safeguard clause was invoked against Bulgaria in order to suspend some benefits stemming from EU transport legislation and for that purpose the European Commission adopted a regulation (within the meaning of art 288 TFEU). See: Commission Regulation (EC) 1962/2006 of 21 December 2006 on the application of Article 37 of the Act of Accession of Bulgaria to the European Union [2006] OJ L408/8. See also Commission Regulation (EC) 875/2008 of 8 September 2008 repealing Regulation (EC) No 1962/2006 [2008] OJ L240/3.
} 
Council in this respect'. In reality, it is hard to imagine the European Commission taking a decision against the will of the Council of the European Union. Thus, one could assume that the decision to lift the safeguard clause will require the approval of the Member States.

\subsection{Justice and Home Affairs safeguard clause}

Article 39 of the Act provides for a unilateral JHA safeguard clause, the mechanics of which and life span are very similar to the internal market clause discussed above. ${ }^{120}$ It can be invoked by the European Commission (acting ex officio or at the request of a Member State) if there are shortcomings or if there is an imminent risk thereof when it comes to compliance with legislation adopted by the EU institutions pursuant to Part Three, Title V of the TFEU, ${ }^{121}$ as well as of acts adopted by the institutions before the entry into force of the Treaty of Lisbon. ${ }^{122}$ The European Commission has the obligation to consult the Member States before any decision is taken. It is not entirely clear what type of legal acts the European Commission has the competence to adopt. Alas, article 39 of the Act again uses the vague term 'measures'. However, we know what these measures may amount to. Mainly, they may take the form of a temporary suspension of the application of relevant provisions and decisions in the relations between Croatia and any other Member State or Member States, without prejudice to the continuation of close judicial cooperation. In response to progress made by Croatia in rectifying the identified shortcomings, the Commission may adapt the measures as appropriate after consulting the Member States. The modus operandi for revocation of the JHA safeguard clause is the same as for the internal market safeguard clause discussed above.

\section{Conclusions}

In October 2012, the European Commission argued that Croatia meets most of the accession criteria and is on track for accession to the European Union on 1 July 2013. This is subject to ratification of the Seventh Accession Treaty by all Member States of the European Union. As

\footnotetext{
120 The JHA safeguard clause may be invoked even before accession on the basis of the monitoring findings and the measures adopted enter into force on the date of accession unless they provide for a later date. The measures shall be maintained no longer than strictly necessary and, in any case, shall be lifted when the shortcomings are remedied. They may, however, be applied for longer than 3 years as long as these shortcomings persist.

121 Area of Freedom, Security and Justice covering policies on border checks, asylum and immigration; judicial co-operation in civil matters; judicial cooperation in criminal matters, as well as police cooperation.

122 This includes legislation adopted pursuant to Title VI of the TEU or pursuant to Part Three, Title IV of the Treaty establishing the European Community.
} 
argued in this article, this is not fait accompli and, to make things more complicated, an alternative date of entry into force is not envisaged at all. This may prove to be a bonanza for lawyers and a headache for those in political circles. However, if everything goes according to plan Croatia will accede on schedule and the Accession Treaty provides a comprehensive framework outlining the terms of accession. As is well known, accession to the European Union opens the door to the EU legal order. In accordance with the principle of the immediate effect of EU law, this 'new legal order' will become applicable in Croatia as of the date of membership in the European Union. The only exception will remain pieces of the acquis subject to transitional periods and various adaptations laid down in the Act on Conditions of Accession and several annexes. Phasing into EU decision-making had already started after the signature of the Accession Treaty on 9 December 2011. When this article went to print, the Croatian authorities had already had the first taste of what it is like to be a part of the EU decision-making machinery. As this article demonstrates, some of the institutional arrangements are well established and are tested elements of the EU enlargement acquis. At the same time, there are a number of idiosyncrasies specific to this enlargement round. They are not only institutional issues but include methods of securing compliance with the conditions of accession. As explained in the last section of this article, the Seventh Accession Treaty provides for an enhanced monitoring mechanism which aims to secure that by the time of accession Croatia complies with the commitments undertaken in the accession process, particularly in the ever sensitive Justice and Home Affairs area, as well as with regard to contentious state aid to shipyards and the steel sector. Time will tell whether the pre-accession conditionality, benchmarking and scrutiny were strong enough to secure full compliance. Time will also tell whether the support shown by the Croatian voters in the accession referendum will hold firm in the years to come. 